\title{
Research observation: Influence of over-wintering feed reg- imen on consumption of locoweed by steers
}

\author{
M.H. RALPHS, D. GRAHAM, M.L. GALYEAN, AND L.F. JAMES
}

Authors are rangeland scientist, USDA/ARS Poisonous Plant Lab, 1150 E $1400 \mathrm{~N}$, Logan, Ut. 84321; county agent, Clayton, N. M.; professor, West Texas A\&M Univ., Canyon, Tex. 79016; and research leader, USDA/ARS Poisonous Plant Lab, Logan, Ut..

\begin{abstract}
Many producers believe cattle grazing wheat pasture during the winter are likely to graze actively growing locoweed when turned onto short-grass prairie in the spring. White locoweed (Oxytropis sericea Nutt, ex T\&G) consumption was compared in a spring grazing study between steers wintered on irrigated 'TAM 105' wheat (Triticum aestivum L.) pasture (Wheat) and steers wintered on native range (Range). Range steers consumed locoweed for $43 \%$ of bites compared to $17 \%$ for the Wheat steers, and began eating locoweed before steers in the Wheat group. We rejected the hypothesis that steers wintered on wheat are more inclined to graze locoweed than steers wintered on native range.
\end{abstract}

Key Words: poisonous plant, Oxytropis sericea, beef cattle, graxing

The High Plains region of northeastern New Mexico, eastern Colorado, and the Oklahoma and Texas panhandles is an important grazing area for stocker steers and heifers. Many stocker cattle are wintered on wheat pasture then shipped to the High Plains region to graze rangeland for the summer. When cattle arrive in May, warm-season perennial grasses typically have not initiated growth, but white locoweed (Oxytropis sericea Nutt, ex T\&G), a cool-season species, is generally in full bloom.

Ranchers speculate that cattle previously grazed on wheat pasture are likely to graze the green, actively growing locoweed in preference to dormant warm-season grasses, because they are conditioned to eating succulent forage. Conversely, cattle that are native to the area and wintered on dormant range should be more familiar with the vegetation community and conditioned to grazing dry grasses, and thus avoid grazing locoweed. The objective of our study was to test the hypothesis that steers wintered on native range would avoid locoweed, while steers wintered on wheat pasture would readily graze locoweed in the spring.

\section{Methods}

Phase 1, Winter Grazing of Wheat or Native Range.

Twelve Hereford steers $(160 \mathrm{~kg})$ were purchased in November 1993 from a ranch near Des Moines, N.M. and allotted randomly

Manuscript accepted 12 May 1996. to wheat or native range winter feeding regimens at the New Mexico State Univ. Livestock Research Center at Clayton, N.M. Six steers were placed on irrigated 'TAM 105' wheat (Triticum aestivum L.) pasture from 10 January until 29 March (Wheat group). The wheat pasture was 50 ha and the steers were grazed with 95 other steers and heifers. The other 6 steers were wintered on 25 ha native range (Range group) adjacent to the wheat pasture, and supplemented with $0.45 \mathrm{~kg} /$ day protein supplement (95\% soybean meal, $5 \%$ molasses, DM basis). Both groups received a salt/mineral mix (salt $20 \%$, limestone $15 \%$, dicalcium phosphate $29 \%$, magnesium oxide $22 \%$, soybean meal $9 \%$, and other trace minerals) free choice throughout the winter and during the spring locoweed grazing trial. At the end of the winter conditioning period, steers on Wheat weighed $236 \pm 8$ (SE) $\mathrm{kg}$, and those on Range weighed $226 \pm 18 \mathrm{~kg}$.

\section{Phase 2, Spring Locoweed Grazing Trial}

The site of the spring grazing trial was $16 \mathrm{~km}$ south of Des Moines, N.M. on a silty clay loam soil that was previously cultivated but reverted to short-grass prairie. Dominant species included bluegrama [Bouteloua gracilis (H.B.K.) 1ag. ex Steudel], western wheatgrass [Elymus smithii (Rybd.) Gould], squirreltail [E. elymoides (Raf.) Swezey], and white locoweed.

Four triangular pastures ( 3.4 ha each), which radiated out from a central set of corrals, were arranged in 2 blocks ( 2 pastures per block) with a $15-\mathrm{m}$ alley separating the 2 blocks. Treatment groups were allotted randomly to blocks, and the 6 steers in each group were allotted randomly to 2 pastures (replications) within each block (3 steers per pasture). Blocks were separated to prevent steers in one treatment group from observing steers in the other treatment group, since social facilitation is a strong force that influences animal's diet selection (Ralphs et al. 1994a). Individual steers served as experimental units, whereas the pastures were merely the area where the effects of the treatment were expressed. Groups were rotated to the pastures in the other block midway through the study to minimize any pasture differences in diet selection.

Steer diets were estimated using a bite count technique (Lehner 1987). Each steer was observed for 5 -min periods during the major morning and evening grazing periods each day. Generally, 3 to 6 observation periods were obtained from each steer every day. The number of bites of each forage class (cool-season grass, warm-season grass, forb, or locoweed) was recorded and the percentage of each class in the diet was calculated. 
Standing crop was sampled at the beginning and end of the study. Ten $1 \mathrm{~m} \times .25 \mathrm{~m}$ plots were systematically located at 20 . step intervals along a transect in each pasture. Forage classes were clipped, dried in a forced-air oven at $60^{\circ} \mathrm{C}$ for 48 hours, and weighed. White locoweed samples were analyzed for swainsonine concentration (Molyneux et al. 1989).

Blood samples were drawn from the jugular vein of each steer at the beginning and end of the trial, and serum was separated by centrifuge and frozen. Swainsonine concentration in the serum was measured by an $\alpha$-mannosidase inhibition assay (Stegelmeier et al. 1995) to estimate intoxication level. Correlations were made between percentage of locoweed bites and swainsonine concentration in the blood.

Percentage of each forage class in the diet was compared between groups and over days of the trial in a split-plot analysis of variance. We tested the hypothesis that the Wheat steers would consume more locoweed than the Range steers (1-tailed test). Groups were the main plot and differences were tested by the steer within group factor. Day was the split plot in time, and day and the day $X$ treatment interaction were tested by the residual error. Differences in percentage of locoweed bites between pastures was tested to verify that there was no pasture bias.

\section{Results}

At the beginning of the spring grazing trial, white locoweed was growing rapidly, new leaves of cool-season grasses western wheatgrass and squirreltail were 5 to $10 \mathrm{~cm}$ long, and few forbs other than locoweed were growing. Standing crop at the beginning of the study for dormant warm-season grasses was $306( \pm 19$ SE) $\mathrm{kg} \mathrm{ha}^{-1}$, cool-season grasses was $66( \pm 13 \mathrm{SE}) \mathrm{kg} \mathrm{ha}^{-1}$, locoweed was $152( \pm 18 \mathrm{SE}) \mathrm{kg} \mathrm{ha}^{-1}$, other forbs was 70 ( $\pm 16 \mathrm{SE}$ ) $\mathrm{kg} \mathrm{ha}^{-1}$, and snakeweed was 49 ( $\left.\pm 11 \mathrm{SE}\right) \mathrm{kg} \mathrm{ha}^{-1}$. The stocking rate during the 21-day trial was $1.13 \mathrm{ha} /$ steer. A moderate stocking rate for this region is $6 \mathrm{~h} / \mathrm{steer}$ for a 5 -month grazing season.

Steers from both groups preferred the cool-season grasses at the beginning of the study ( 50 to $70 \%$ of bites). After the first week, Range steers began eating locoweed and consumed it for 50 to $80 \%$ of their bites (Fig. 1). Steers assigned to the Wheat group started eating locoweed after the second week, and consumed similar amounts of locoweed as steers in the Range group for the remainder of the trial. Mean locoweed consumption by the Range steers was $43 \%$ of bites, compared to $17 \%$ by steers in the Wheat group $(P<0.01$, Table 1$)$. There was also a treatment $X$ day interaction $(P=0.02)$, which verified that the Range steers began eating locoweed before the Wheat steers (Fig. 1). There were no differences in percentage of locoweed bites between pastures $(\mathrm{P}>$ 0.10 ).

Swainsonine concentration in blood serum of the Range steers was three-fold greater than in the Wheat steers ( $387 \mathrm{vs} 126 \mathrm{ng} \mathrm{ml}^{-1}$, $P=0.001$ ) at the end of the trial, which indicated that Range steers were more severely intoxicated than the Wheat steers. There was a strong correlation between percentage of locoweed bites and swainsonine level in the blood $(r=0.90)$. Swainsonine concentration in white locoweed increased from $0.012 \%$ (air dry weight) at the beginning of the trial when locoweed was vegetative, to $0.028 \%$ at the end when it was in the flower bud stage of development.

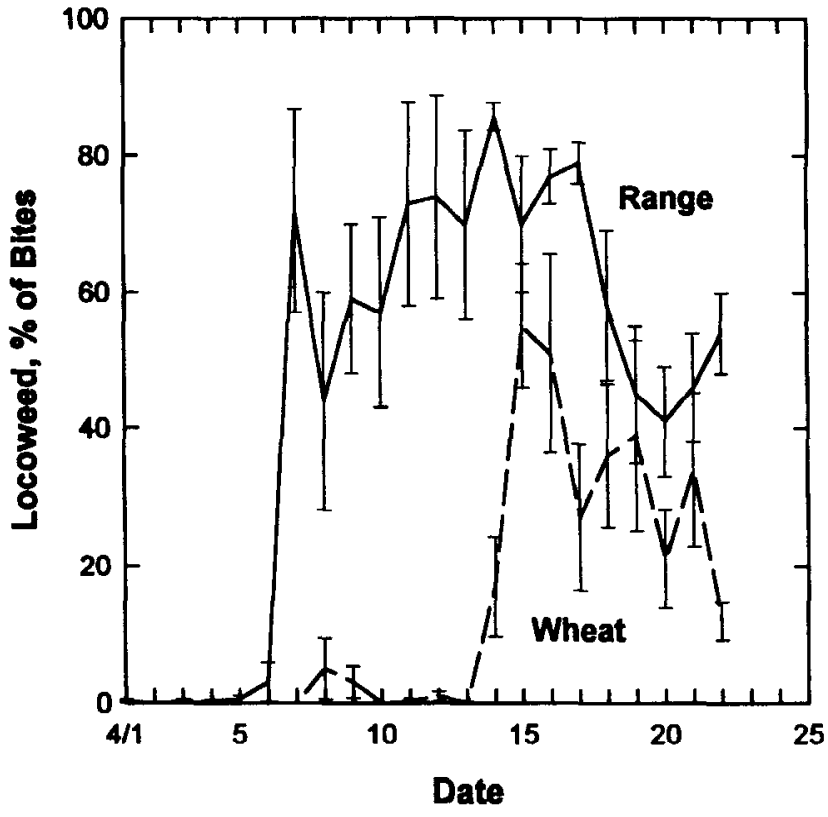

Fig. 1. Percentage bites of locoweed (bars are standard errors) for steers grazing short grass prairies after wintering on wheat pasture (Wheat) or native range (Range).

Steers from both groups continued to graze on the site for a subsequent aversion trial (Ralphs et al. 1997), and became lethargic and visibly intoxicated. However, they ceased grazing locoweed when warm-season grasses began rapid growth in late May. There was no swainsonine in blood serum at the end of the aversion trial when measured on 6 June 1994.

\section{Management Implications}

Our original hypothesis was that cattle wintered on native range would avoid grazing locoweed, while cattle wintered on wheat pasture would readily graze actively growing locoweed in the spring. Based on data from this trial, we reject this hypothesis. Steers wintered on native range began eating locoweed before those wintered on wheat pasture and consumed more of it in the spring.

We do not suggest that cattle wintered on range are more likely to consume locoweed compared to those wintered on wheat pasture. During the last part of the study, both groups of steers grazed similar amounts of locoweed and were visibly intoxicated. Results from previous research using native, mature cows (Ralphs et al. 1993, 1994b) clearly demonstrated that cattle will select large amounts of locoweed in the spring when warm-season grasses are still dormant. However, steers in this study, and all cattle in previous grazing trials, ceased grazing locoweed

Table 1. Means of forage classes in steer diets in spring grazing trial (\% $\pm \mathrm{SE})$.

\begin{tabular}{lcccc}
\hline \hline $\begin{array}{l}\text { Winter } \\
\text { treatment }\end{array}$ & $\begin{array}{c}\text { Cool season } \\
\text { grass }\end{array}$ & $\begin{array}{c}\text { Warm-season } \\
\text { grass }\end{array}$ & Locoweed & Forbs \\
\hline Range & $41 \mathrm{a} \pm 3$ & $13 \mathbf{a} \pm 2$ & $43 \mathrm{a}+4$ & $2 \mathrm{a} \pm .2$ \\
Wheat & $46 \mathrm{a} \pm 2$ & $33 \mathbf{b} \pm 3$ & $17 \mathbf{b}+5$ & $5 \mathbf{a} \pm .6$ \\
\hline
\end{tabular}

${ }^{\mathrm{ab}}$ Means in a column followed by different letters are different $(\mathrm{P}<0.025)$. 
when warm-season grasses began growth. These data reinforce the management recommendation (Ralphs et al. 1993) to wait until warm-season grasses are growing and abundant before moving stocker cattle to locoweed-infested short-grass prairie on the High Plains.

\section{Literature Cited}

Lehner, P.N. 1987. Design and execution of animal behavior research: an overview. J. Anim. Sci. 65:1213-1219.

Molyneux, R.J., L.F. James, K.E. Panter, and M.H. Ralphs. 1989. The occurrence and detection of swainsonine in locoweeds. pp. 100-117. In: L.F. James, A.D Elbein, J.R. Molyneux, and C.D. Warren (Eds). Swainsonine and Related Glycosidase Inhibitors. Iowa State Univ. Press. Ames, Iowa.
Ralphs, M.H., D. Graham, and L.F. James. 1993. Seasonal grazing of locoweeds by cattle in northeastern New Mexico. J. Range Manage. 46:416-420.

Ralphs, M.H., D. Graham, and L.F. James. 1994a. Social facilitation influences cattle to graze locoweed. J. Range Manage. 47:123-126.

Ralphs, M.H., D. Graham, and L.F. James. 1994b. Cattle grazing white locoweed in New Mexico: influence of grazing pressure and phenological growth stage. J. Range Manage. 47:270-274.

Ralphs, M.H., D. Graham, M.L. Galyean, and L.F. James. 1997. Creating aversions to locoweed in naive and familiar cattle. J. Range Manage. 50:(4).

Stegelmeier, B.L., L.F. James, K.E. Panter, and R.J. Molyneux. 1995. Serum swainsonine concentration and $\alpha$-mannosidase activity in cattle and sheep ingesting Oxytropis sericea and Astragalus lentiginosus (locoweeds). Amer. J. Vet. Res. 56:149-154.

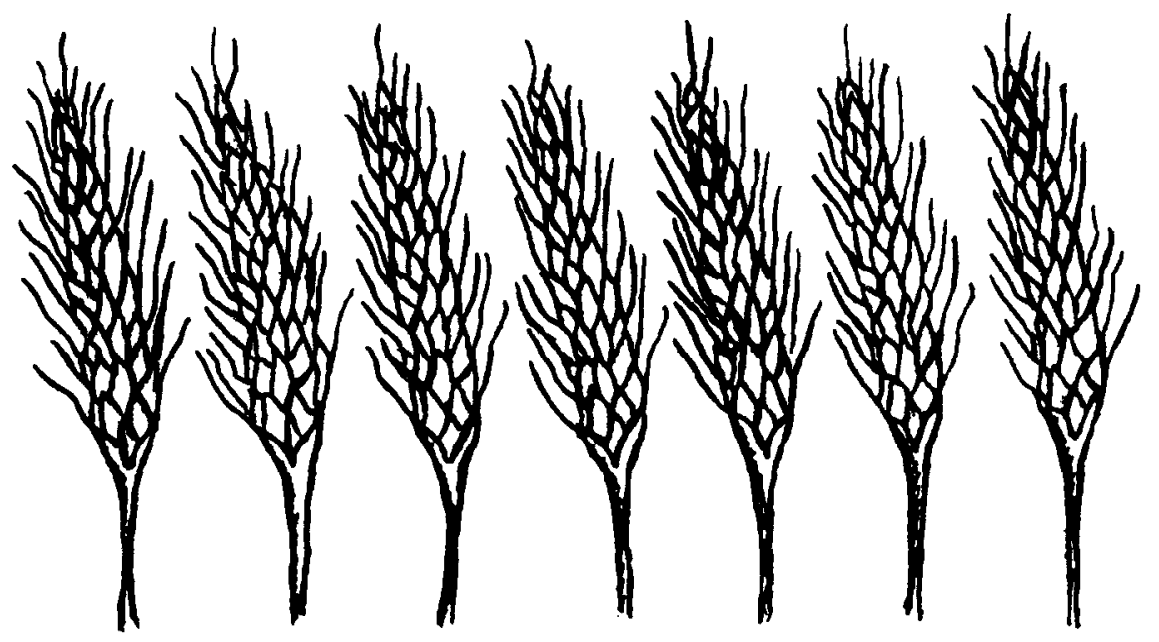

